\title{
Salvation for All Creation: \\ The Meaning of the Atonement In Colossians 1: 15-23 from Mosehe's Perspective and the Implication for Eco-Theology in the Protestant Church in Southeast Sulawesi
}

\author{
Salmon Pamantung \\ Sekolah Tinggi Agama Kristen Negeri (STAKN) Toraja \\ spamantung@yahoo.com
}

\begin{abstract}
The Protestant Church in Southeast Sulawesi (GEPSULTRA) is placed by God in an area where the level of environmental damage is massive, due to mining activities by state-owned and multinational mining companies. But the Church is "silent" in that context. This attitude is strongly influenced by the soteriological view that places nature outside the work of salvation. GEPSULTRA must develop ecotheology/soteriology by using the local wisdom of the Tolaki people. What is the meaning of the atonement of Christ in Colossians 1: 15-23 from the perspective of the mosehe ceremony in Southeast Sulawesi? In the mosehe rite, the pattern of order is found as follows: metanoia (guilty of disharmony), catharsis (efforts towards harmony) and paripatia (creating harmony). With this pattern, reconciliation is understood as reconciliation which is not only personal reconciliation, but also includes cosmic reconciliation. God's redemption or reconciliation is reconciliation for all of creation and at the same time a re-creation of all creation.
\end{abstract}

Keywords: Eco-theology, Colossians, Mosehe, GEPSULTRA.

\section{Introduction}

Environmental destruction, loss of a wide variety of flora and fauna and a significant increase in the earth's temperature are actual themes that are widely discussed in various forums and mass media. Analysis and argumentation on ecological problems was presented by experts from various disciplines. This also shows that ecological problems have become an inevitable global issue today.

Environmental damage is divided into three categories, first: forest damage, damage to the soil, damage to coral reefs and damage to the ozone. Second: the extinction of natural resources, the extinction of biological resources and the extinction of springs. Third: global climate chaos due to the greenhouse effect.[1] These damages cause increasingly complex problems as a direct or indirect result of environmental damage. These problems include health issues, injustice in the use of natural resources and even damaging, polluting and exploiting natural resources.

An environmental crisis is a crisis of life. This is a matter of life and death. It is a matter of how we must act in real terms to save our lives together or are we destroyed by landslides, floods, disease or even death from overheating and starvation due to crop failure? We must be more sensitive and act more effectively to protect the environment. 
The main cause of this earth/environment crisis is the pattern of modern human approaches to nature that are wrong. Humans do not treat nature as friends and only see as mere objects. Nature is seen as a means, a mine of wealth, an energy source, a source of wealth that must be exploited for human needs. This is what causes environmental damage even more severe. Environmental ethics emerged as a reaction to the interpretation of the word of God that justifies the practice of unlimited natural exploitation, causing environmental crises. Humans are less aware, "by destroying the nature of creation, humans are actually destroying their own civilization"

When viewed from the Christian point of view, it can be said that the topic of environmental destruction has hardly ever received attention. The Protestant Church in Southeast Sulawesi (Gereja Protestan di Sulawesi Tenggara/GEPSULTRA) through sermons and messages from the pulpit discusses this topic, even though the environment is an important place for the survival of humans and other creatures. One reason is the concept of salvation which only pays attention to the safety aspects of the human soul (anthropocentrism). Safety is not seen as a whole and holistic, so that environmental safety does not get a place and attention. Theological style which only discusses God without regard to creation, is not a strong theology. Sunarko and A. Eddy Kristiyanto wrote "our attitude to the earth depends on our attitude to God who created the earth"[2]. The phrase shows that theology is not limited to talking about God, but expressed in actions and practices related to nature and the environment. Therefore theology needs to be interpreted as the intellectual expression of religion, so that its understanding becomes broad and relevant to responding to contemporary challenges including ecological or environmental issues.

The Church (Gereja Protestan di Sulawesi Tenggara/GEPSULTRA) is in such a context. Besides being known as nickel mines in Pomalaa and asphalt mines in Buton, several new mining sites have begun to emerge such as sand mines in several places, Bombana gold mines in 2008 and most recently, gold mines in the Nature Park conservation area which have been operating since 2017.

In fact, as reported by kompas.com, according to the native Regent Kolaka, Southeast Sulawesi, Ahmad Safei, in 2017 ago has happened deforestation in protected areas Mangolo Nature Park with an area around five hectare. This condition occurs due to the existence of gold mining activities at the location which is located in Ulunggulaka District. This happened because the miners dug out gold to dig gold to a depth of 15 meters and after it was finished, just left it[3]. The same thing happened in the case of the bombana gold mine discovered in 2008. The Regional Government of Bombana noted that up to now, the number of remaining holes had reached hundreds of thousands and forest destruction. Not only that, the environmental damage also hit the coast of Kolaka, Southeast Sulawesi. In mid 2017, the Minister of Fisheries and Maritime Affairs, Susi Pujiastuti, conducted a sudden inspection in the fishing village of HakatutobuPomalaa. Minister Susi was furious to see that the sea was polluted by sediment from the nickel mining operation which resulted environmental disasters [4].

Interpretation of Scripture texts that are strongly influenced by anthropocentrism views, both in the theology of creation and in theology of salvation make the churches not see nature as the purpose of God's salvation, instead of looking at nature (cosmos) as part of the evil forces that oppose God. Therefore it is necessary for the churches to reinterpret the biblical texts by considering nature as the same entity as humans. This can be done if we are shifting from an anthropocentrism to an ecocentrism views. One of the biblical texts related to salvation theology is Colossians 1: 15-23. 
What is the cosmic-ecocentrism dimension that found in the mosehe rite? How do toundersatand the reconciliation of Christ in Colossians 1: 15-23 from perspective of the mosehe ritein order to contextualize eco-theology in Southeast Sulawesi? The local wisdom in the rites of mosehe in Tolaki culture, is very valuable. Itcan be used to help GEPSULTRA to see the cosmic reconciliation in Colossians 1: 15-23. GEPSULTRA should be more sensitive to face environmental damage there and take concrete steps to repair the environmental destruction. The church must act and take an active role in overcoming environmental damage, if we still want to see the future of creation.

\section{Methodology}

Stephen Bevans in his book, Models of Contextual Theology underscored the importance of doing theological contextualisation work by paying attention to the interactions of Scripture elements, church dogmas, local culture, social change, personal and communal experiences. Considering reality of socio-cultural-religious is important thing in interpreting the Bible from and through context [5].

Contextual hermeneutic of the Scriptures are attempts to read and interpret biblical texts in a specific cortex of life as possessed by readers. In order to develop Indonesian contextual hermeneutics, we need to cultivate the socio-cultural context of Indonesia (Asia) and the diversity of religious/religious traditions as important in interpreting the Bible [6].

In this research, I usethe local wisdom in rite of Moseheto understand the meaning of the reconciliation if Christ in Colossians 1: 15-23 in order tocontextualise eco-theology at The Protestant Church in Southeast Sulawesi.

\section{Result and Discussion}

\subsection{Anthropocentism Views in Christian Theology}

Lynn White Jr., in a famous essay The Historical Roots of Our Ecological Crisis, states that the Industrial Revolution marked a turning point in the history of human relations and the natural environment.[7] In the climate of the Industrial Revolution, scientific hypotheses are mated to the possibilities of technology, and the fruits of that marriage are an increase in both human desire and ability to exploit, even destroy the natural environment.

Furthermore, for White Jr., the "mentality of the Industrial Revolution", where the natural environment is merely seen as a resource for human consumption, has its roots in the attitude of Christianity since the Middle Ages towards nature. He identified at least two sides of Christianity's attitude toward nature that became "the historical roots of the ecological crisis": (1) The Bible, in a certain sense, legitimizes human domination over nature, and (2) various dogmas of Christianity which clearly distinguish between human ( which is created in accordance with the image or image of God) with other creations, which are considered to have no "soul" and "reason" - and, therefore, have a lower degree than humans. Both sides, for White Jr., provide the background for anthropocentrism tendencies. It is the anthropocentrism that makes people only see the natural environment as a resource for human consumption that can continue to be explored and exploited for the benefit of humans[8]. 
Regarding the first side, the passage from Genesis 1:28 is a classic example. In the text, it is said that God blessed people and said to them, "love and multiply; fill the earth and conquer it, rule over the fish in the sea and the birds in the air and over all the animals that crawl on the earth ". The word "conquere" in the text of Genesis 1:28 is translated from the Hebrew word radah which is used in other parts of the Old Testament in the context of enforcing power. While the word "dominion" is translated from the Hebrew word kabash which again casts a nuance of enforcing power by force - even militaristic and cruel! Compare, for example, with the text of Joshua 18: 1, where Joshua is told to "conquer" (kabash) the Canaanites with cruel military power.

As for the second side, it seems that we don't need to go too far to look for dogmatic concepts that are complex. Take the teachings on "incarnation" as an example. In the Gospel text according to John 1:14 it is told that "the Word became flesh" - indeed, in the Greek text it is stated o logos sarxegeneto, which literally means "the word has become flesh". So, in the traditional doctrine of the incarnation, the full revelation of God is lived only in the human body (flesh) (Jesus Christ) and for saving only humans! In line with White Jr., John Salmon, in his paper, Christology and Climate Change, states Christological doctrines, especially incarnations, play a major role in seeding and strengthening the tendency of anthropocentrism[9].

The explanation is reinforced by the view of Hannah Arendt in Human Condition which shows that the roots of anthropocentrism are also found in Christian (Protestant) doctrine, which "approves" and triggers human behavior to over-exploit nature. By the influence of the Enlightenment and also the Reformation of the church, there was human alienation of his world[10]. The capacity for humanity is further developed in the hope that it can "subdue" nature, the earth. In its development, the right of private ownership was increasingly strengthened in the socio-economic order of the people in the European plains as the process of industrialization, production patterns and consumption increased sharply. Such patterns underlie and support human behavior to overexploit and exploit nature.

When Christianity as a whole is still being explored by anthropocentristic tendencies, the Protestant tradition is even more so. The church reform movement stems from the anxiety of the reform figures on the teachings of the Roman Catholic tradition regarding the role of God, the church, and each individual person in human salvation. Thus, the writings and teachings of the reformed church also concern themselves with these themes: God, the church, and the people (read: human). Talk about the safety of non-human creation is also lacking a place. John Calvin, for example, builds his theology around the theme of God and the human soul - a broader picture of creation, both human and non-human, only flashes in the background.

The energy of the Protestant tradition also seemed drained in the struggles about how Christianity should understand human salvation: sociohistorically or worldly? Psychologically or existentially? Morally or mystically? In short, the Protestant tradition continues to be preoccupied with matters relating to mere human interests, even if God is spoken of, certainly in relation to human interests.

\subsection{Eco-theology: An Urgent Christian Theological Agenda}

For Christians, the silence or silence of Jesus' followers over the exploitation and domination of nature is a sin. Seizing of natural resources is seizing nature which incidentally belongs to God. Faith does not die in doctrine and the Bible, but it lives in the midst of the screams of victims seized by arbitrary officials and corporations. Thomas Berry said, "We 
should be clear about what happens when destroying the living forms of this planet. First consequence is that we destroy the modes of divine presence" [11].

Jurgen Moltmann said, "Nature is not our property, neither are we only the part of nature." Human superiority over nature destroys ecosystems. The principle is "non-human world out there"[12]. A stronger anthropocentric footing and glasses make humans like wild predators. Even the foothold of the biblical text is the justification for "ruling" over nature. A misinterpretation from year to year Genesis 1:26, rather to "Subduer rather than cake taker".

Even Kwok Pui Lan in his article, Ecology and Christology, saw that anthropological Christology studies were incompatible with Asian culture, especially Indonesia. For him, the emphasis in Asia is cosmology. Humans are one with nature [13]. The path taken is the concept of panentheism, that is, God exists in all of these universes. God lives with the cosmos, but the transcendence is not lost. This perspective forms creation is part and lives together with God (Alive with God). Sallie McFague believes that the world is thebody of God (universe is the body of God), so when Jesus became human / became flesh. That is also the body of the universe (Body of the universe) [14].

\subsection{Living with a Community of Creation}

By looking at the case of exploitation of natural resources, human life must move from individualism to "person in mutual relationship". Humans are interconnected with all creation, including nature. Only by participating in the community of creation, humans become a dignified entity. The struggle is to defend the integrity of creation. Because the basis of all ethics is respect for life (the reverence for life).

The created community is a biotic community that is called for by Aldo Leopold in A Sand Country Almanac, which is a family of networks that promote mutual interdependence. Only by establishing brotherhood with the earth's community, our vocation is to reject absolute discrimination and hierarchy over nature. Like Kwok Pui Lan said that it merges with the reality of nature, which does not have "the inner" and "the outer"[15]. Humans become whole, unity with nature, because it was created from the dust of the earth. In the Hebrew language is adamah, but on the other hand, humans are also born from the mother's womb. I still remember the words of the teacher as a child, who said that Francis of Assisi was a famous monk, theologian and religious leader. The saying, "The monastery is the whole world, where every creation of God exists and lives." Our job is to fight the culture of death and build a culture of life. If the church was previously echoed by extra ecclesiam nulla sallus (outside the church there is no salvation), now the idea has changed, namely extra solidaritatemvictimarumnullasallus (out of solidarity with victims, there is no safety). Civil society movements, including the church, must be critical of the 3 axis of power (communitymarket-state). Only with spiritual transformation, we fully realize that the destruction of nature is our shared responsibility. The call for ecological repentance must be sounded at all times, wherever it is located that the sin is due to the environment.

Karel Philip Erari became very important for the study of (Christian) ecoteology in Indonesia. Erari also based and developed his ecoteological ideas from McFague's appeal. Erari, who views the relationship between humans and land on Papua as a theological problem, uses the insight from McFague to read and interpret the Gospel text according to John 1: 1-14.[16] Considering McFague's appeal, Erari invites us not to simply identify the statement "The Word has become flesh" with the statement "The Word has become human": flesh (sarx) not only refers to humans, but to all creation. For Erari, the Word was not merely, exclusively, incarnated as a human "flesh", but also as a "flesh" of all non-human creations. 
Mc Fague's appeal and Erari's fresh interpretation of the concept of incarnation marked a very radical paradigm shift: from an anthropocentric paradigm to a the anthropocosmic (the anthropocosmic) paradigm. Radical because in the the anthropocosmic paradigm, both Christianity and all stakeholders of the environmental movement are no longer able to survive with utilitarianistic environmentalism which ultimately centers on human goals and interests viewed from a theanthropocosmic perspective, all attempts at utilitarianistic environmentalism, rather than utilitarian environmentalism which ultimately centers on human goals and interests - viewed from a theanthropocosmic perspective, all attempts at utilitarianistic environmentalism, rather than bring us to rise from the pool of ecological crisis, it will drown us even more because at its heart is still pulsating anthropocentrism which is at the root of the ecological crisis itself. Radical because while, on the one hand, being critical of ecocentrism biases in both the Bible and Christian dogma, the cosmic paradigm, on the other hand, enables Christianity to re-read the Bible and reconsider its dogmas fresh in the midst of the ecological crisis. Regarding Christian dogmas that seed and reinforce anthropocentrism tendencies, what McFague and Erari have done, has given us an excellent example of how we should reconsider Christian dogmas.

During this time, Christianity has loved to proclaim the "great commission" of the Gospel according to Matthew: "All authority has been given to me in heaven and on earth, so go, make all nations My disciples and their babtis in the name The Father and the Son and the Holy Ghost, and teach them to do all things that I have commanded you "(Matt. 28: 18-20). Without intending to downplay the importance of the "great commission" of the Gospel according to Matthew, in the midst of this ecological crisis, it seems that Christianity also needs to echo the "great commission" of the Gospel according to Mark: "Go into all the world, preach the Gospel to all creatures" (Mark 16:15). So, we are mandated by Jesus Christ to proclaim the news of joy not only to all nations (humans), but to all creatures - both human and non-human!

\subsection{Ecological Dimensions in the Rite of Mosehe}

Gepsultramember come from various ethnic or ethnic groups, not only native (Tolaki) but also immigrant ethnicities, such as Toraja, Minahasa, Ambonese Sangir, Batak and others. There are three main tribes who inhabit the Southeast Sulawesi region, namely the Butonese who inhabit Buton Island, the Muna tribe who inhabit or live in Muna Island, and the Tolaki tribe who inhabit Kolaka Regency, Konawe Regency, South Konawe Regency and Kendari City. The Tolaki tribe are mostly Muslim and some are Christian, Catholic, Hinduism and Budhism [17].

The conceptions of nature, humans, gods, spirits and supernatural powers are the Tolaki's religiosity system. In their belief, there is a main deity called SangiaMbu'u, that can be interpreted as the sky god and the chief deity[18]. Tolaki's people also have a view of soteriology, namely safety directing human life to achieve a prosperous and happy life. Safety is realized if they live without disasters, abundant fields, longevity and have a harmonious relationship with Sangia, other creations and the universe.

One of the important rites in the Tolaki tribal community is the moseherite, which is the ritual of atonement/purification. The mosehrite usually do when something goes wrong or a violation of the customary (sara) in which the breach can be disastrous (Abala) to humans, be such a natural disaster, disease, death and disruption of the human relationship with the natural surroundings. To refuse abala, the moseherite was held[19]. During the ceremony in the use of eggs or animal sacrifice. Type of sacrifice used in mosehe rite depending on the size of or 
severe severity of the breach, for example sehe ndi'olu(eggs), sehe manu (reconciliationby sacrificed a chicken), sehe ngginiki(reconciliationby sacrificed a buffalo). Mbusehe(ceremonial leader) says a prayer to SangiaMbu'u and then offer sacrifices and ask for blessings to avoid disaster.

The moseherite or atonement ritual as well as the rejection of reinforcements is a sacred rite that explains man's relationship with sangia, where humans feel themselves inferior and feel besieged by the power of the gods. Thereforehumans perform various rites that are sacred by way of surrender and devotion, because humans expect something (salvation and release from disaster) from the 'highest reality'.

The mosehe rite is part of the sara(read: religion) which has been established and given by SangiaMbu' $u$ to the ancestors of the Tolaki tribe. Sara's function is to preserve the universe and all its contents, so saraby the Tolaki is called a guide to light. The importance of sarain human life is evident in the necessity of the Tolaki people to carry out saraitself. For example, a person may unmarry/marry a sister-in-law (tumutuda). If these customs are violated, they will be disastrous (abala). As told by Binethat in Wolio village there was a young man who had violated the tumutuda custom[20]. Realizing the violation he had committed, the young man planned to run away. After successfully escaping from the village, they settled in anothervillage. Then they finally blessed with child. But child only a week old and eventually die. And so on with every new born children. All efforts have been made, either through health science or visiting a shaman, but all of those efforts did not work. In a dream, the husband dreamed, he met his grandfather, who suggested that he and his wife return to the village and acknowledge all the violations of the customs that they had done before. The violation of "adat" that they have done, caused their children were diath and also caused an outbreak of disease to attack the villagers and resulted in the failure of agricultural products in the village where both came from. They must do the moseherite to refuse reinforcements and at the same time make peace with SangiaMbu'u, with all the people, and with nature. The next day they immediately headed to the village where they came from, and there was held the moseherite. Eventually they were welcomed back into the village community. Sometime after the moseherite was carried out, they have been blessed with children.

After the moseheceremony/ritewas held, the Tolaki tribe believed that all disasters had been spared their lives. This Tolaki concept of reconciliation that contains sociological and cosmological values is closely related to their view of life about the "unity and harmony" of human life with the universe.

Starting from the above understanding, in connection with efforts to build a contextual eco-theology for Gepsultra, it is deemed necessary to appreciate the values contained in the Tolaki moseherite, especially the concept of reconciliation and its meaning in Tolaki life. The concept of reconciliation taught by Gepsultraemphasises individual reconciliation, because repentance from sin is considered a renewal of personal morality. This kind of reconciliation or salvation has not shown any connection between atonement with social and ecological problems. Therefore it is not surprising that church members ultimately lack sensitivity to ecological damage and social problems in carrying out their duties and missions.

Meanwhile, the concept of reconciliation in Christianity refers to the figure of Christ who is often referred to as the atonement sacrifice. From some parts of the biblical text, especially the New Testament, one of the parts that deal with this topic can be found in Colossians, especially Colossians 1: 15-23. 


\subsection{The Role of Christ in Creation and Anotement According to Colossians 1: 15-23}

\section{a) The Role of Christ in Creation}

The role of Christ in creation can be seen in verses 15-18. Christ in verse 15 is called the image of the invisible, first fruits of God, above all created. Christ as the image of God is a term that is widely used in the Old Testament and the thought of Judaism, namely God's Wisdom[21]. Proverbs 3: 19 and 20 contain testimonies that "with wisdom the Lord laid the foundation of the earth". The testimony of Proverbs shows the role of wisdom in the process of creation, that wisdom acts as a mediator in creation.

The writer to the Colossians mentions Christ as the image of God which points to the role and position of Christ as the intermediary in creation. This is then confirmed in verse 16, that "because in Him was created all things, in heaven and on earth."[22]

The using of the aorist verbektisqhis used to describe the role of Christ in the past creation, and the passive perfection verb in the clause verse 16 shows the continuity of the existence of the creation. Further in verse 17 it is stated that Christ is before all things and everything is in Him. This statement of verse 17 again emphasises Christ's identification with Wisdom (see Proverbs 8: 22-31). Even Christ has the main position, over everything that has been created. Governments and authorities and everything that is in heaven and on earth, visible and invisible in submission to Christ.

By changing the cosmological perspective into a soteriological perspective, the writer of the Colossians affirms that Christ is the head of the body, namely the church/congregation (verse 18). The use of the concept of organs is intended to explain the relationship between Christ as the head governing the members of His body, the collection of believers. Believers put their whole life and hope in Christ. It is said so, because Christ is the firstborn from the dead. The clauseinaindicates that the resurrection of Christ from the dead shows that $\mathrm{He}$ "became" (verb aorisgenhtai) "main" (prwteuwn) of everything.

\section{b) The Role of Christ in the Atonement}

The role of Christ in the atonement is found in verses 20-23. The Atonement (kallasw) is a word that is widely used in Greek literature, the majority of which always has a secular meaning, which refers to the situation of restoring relations. The basic idea of using the word katallasw is two parties who are in a hostile atmosphere and hate each other. While usage in the New Testament refers to the dispute and restoration of the relationship between humans and God [23].

\section{c) Means of the Atonement}

In verse 20 it contains a witness that the initiative of reconciliation or reconciliation is from God. The previous passage, Article 1: 12-14 states that God who serves believers as part of what is determined for the saints in the kingdom of light, releases from the power of darkness into the kingdom of His Son, has redemption and forgiveness of sins. Then in verse 22: "... put you holy and without blemish and without blemish before Him ". Everything experienced by believers comes from God. The verb used in verse 20 isapokatallasai(active aorist infinitive form). YusakTridarmanto, quoting F. Platt's view, mentioned that Paul in his 
letters, the use of the active form of the verb "to reconcile" was never used by making God his object. Likewise the passive form of the verb is never used by making God its subject.[24] Colossians 1: 20 also uses the active form of verbs by making God as the subject. Thus, this means that God himself took the initiative to end the feud and improve human relations, even everything with Himself. God does not need to be reconciled with humans, because it is man who is estranged from God, because of his sin (rebellion)[25]. In Romans 5: 10, Paul illustrates that humans are enemies of God because humans are in the bondage of the power of sin, which causes humans to always be hostile to God. Colossians 1:21 mentions that humans live far from God and are hostile to Him in their hearts and minds as evident in evil deeds. The word 'hostile'(evcqroi) in this verse is an expression in an active sense because the word dianoi, a which follows it has a meaning of conscious or deliberate resistance to God[26]. The word in Hanoi, a which is a translation of the Hebrew word bbl (heart) can mean "mind" and "heart". In the New Testament, 'mind' and 'heart' are used together to characterise human thought and behaviour/mentality.

God's initiative to reconcile humans and all things into reality in historical events,tou / ai atojtou / staurou / auvtou /(verse 20). The phrase affirms that the reconciliation of man and the universe is a historical event, the death of Christ on the cross. Events such historical supported by paragraph 22, which states", in the physical body of Christ, through His death. "Christ is not merely a means through which God realised the work of atonement, but also as a manifestation of God's own presence. Therefore in verse 19 it is stated that all the fullness of God dwell in Him. 2: 9 adds the word 'physically'.

The Atonement is an act of God which states how great is God's grace. Acts of reconciliation are carried out through the death of Christ. Verse 18 confirms that Christ was the firstborn, the first to rise from the dead. It is this fact of Christ's death and resurrection that is central to the preaching of the gospel. Even the apostle Paul mentioned that the life of Christ was interrupted in the event of the cross [27].

Colossians shows how the theme of atonement is closely related to the theme of redemption. In Colossians 1: 14 it says that in Him, we have our redemption, the forgiveness of sins. The basic meaning of redemption is the payment of a ransom price. In the New Testament, the death of Christ is considered a ransom price. Jesus himself called himself the ransom paid for the deliverance of the people (see Mark 10: 45). That means Christ is the sacrifice of redemption. The word redemption (apolutrwsin) in verse 14 emphasizes payment for human redemption, where the self or blood of Christ is seen as the price of ransom [28].

\subsection{The Meaning Reconciliation of Christ in Colossians 1: 15-23 from the Mosehe Rites} Perspectives

\section{a) The Atonement of Christ and the Rites of Mosehe in Tolaki's Belief}

In the Tolaki's belief, the safety of one of them is manifested if there is no suffering that befell their lives. In their understanding suffering is seen as a result of evil actions on the part of humans and as a disturbance to the balance of the cosmos. Human mistakes that violate customs, will result in disaster. Therefore, to get relief from the disaster and come back in good relations with the gods, with each other and the universe, humans usually try to get the mercy of the gods, namely by making sacrifices. This is evident in the rite of reconciliation in the midst of Tolaki society. Tolaki people throughout their lives believe always under the supervision of the power of god, sometimes the power of god is considered the same as the 
ancestors. The role of the sacrifice plays a very important role. Therefore the animals sacrificed in the reconciliation rite are animals that are "saved" and respected.

In Colossians it is shown that the atonement is the work of God in Christ, putting people and even everything back in a right relationship with God. The Atonement of God in Christ gives believers redemption and forgiveness of sins (Colossians 1: 14). In adition Christ's atonement also indicates the deliverance or deliverance of believers from the power of darkness (Colossians 1: 13; cf. 2:15). Even though in the text of Colossians 1: 15-23, the word "sacrifice" is not found, but understanding that the reality of believers who have been reconciled is now released from the power of darkness and placing them holy and without blemish and without blemish before God, through atonement by the blood of the cross of Christ (Colossians 1: 20) affirms Christ as the sehe of atonement/redemption. Christ's death on the cross, if met with the Tolaki rite of mosehe, then the death of Christ is an event that reconciles, redeems and releases man and the universe, not only from sin (punishment), but also from the power of darkness. Soit can be said that atonement here also means liberation.

\section{b) Problem of Sin}

The problem of $\sin$ is an important thing related to Christ's identity as a liberator and saviour. The problem of sin is also in turn related to the question of the saving or reconciling nature of Christ's death. Tolaki's people view sin as an act that violates the provisions set by the Sangia(god). Such violations can be seen as rebellion.

Colossians sees acts that opposite God through evil deeds as a rebellion that results in human alienation. Both the Tolaki's people and the Colossians state that the consequences of the rebellion not only affected human relations with the Divine, but also had an impact on the relationship of the universe with the creator.

But there are also striking differences regarding the basis of reconciliation/salvation between the two. Colossians states that the foundation of the atonement was due to God's love which was evident in the event of Christ on the cross (cf. Chapter 1: 6;3:12). Christ's cross and resurrection show how the power of evil and tragedy in the lives of humans and other creatures was conquered by love. Through the death and resurrection of Christ, there is hope for perfection, which is a new creation. This work of saving Christ is broader than the redemption of persons, but will continue until everything is fulfilled in Him.

\section{c) Christ As "Sehe" (sacrifice) for the Cosmic Atonement}

According to the KamusBesar Bahasa Indonesia, sacrifice has the meaning of sacrifice and offering[29]. Sacrifice in the sense of offering is often found in tribal religious practices. There is a close relationship between sacrifice (first sense) and prosperity sense. People who become victims try to get their salvation by bringing sacrifices to the gods, hoping to be given the opportunity to live and avoid disaster. The rite of reconciliation in the Tolaki tribe shows both these meanings of "sacrifice". People who have committed violations result in disasters not only in themselves, but also involve others and all creation. Because of that, a ritual of reconciliation was held, bringing with him sehe (sacrifice/offerings) to avoid disaster. If something happens that is considered a threat to the order of life that will produce disasters, then an act of atonement must be done. An animal as a sacrifice for atonement was slaughtered and its blood smeared on people was considered to be the cause of the disaster.

The act of smearing good blood in the Tolaki tribe is a symbol of sacrifice for others, and at the same time a restoration of the relationship between the guilty person and the 
community, the universe and also the Divine. The guilty person should be punished, but because of the sacrifice, he is saved and atonement is achieved.

By pointing to the blood of Christ on the cross, declares Christ to be a "sacrifice". In the first sense, Christ stands with humans who are in the power of evil. And at the same time Christ is a sacrifice in the second sense. Through Him reconciliation occurs. Christ performs the sacrifice function of others, so that the relationship with God is restored and humanity is saved.

Tolaki's people believe that humans are creatures of "divine" ( Sangia) and at the same time depend on the divine reality. The belief to gods, spirits or spirits gives an illustration that human life is always under the supervision of gods, spirits and spirits. What's interesting in Tolaki's understanding of spirits, called sanggelo, some are good (they can help human) and some are evil. In the mosehe rite the reconciliation and peace has done. However, this reconciliation not only makes relations that are less harmonious be repaired. Through the rite of reconciliation is actually also seen as liberation of humans from the threat of evil powers[30].

In Colossians it is said that through Christ, believers have been released from the power of darkness and transferred them into His beloved children (Col. 1: 13), then Christ's atonement can also be seen as man's deliverance from the powers of darkness. This means that through the work of Christ on the cross, mankind is no longer under these powers (cf. Col. 2:15). The Atonement in the Tolaki tribe and the work of Christ's atonement according to Colossians, both show that mankind is freed from the threat of cosmic powers, even though fundamentally that Christ's death was only once to bring atonement and deliverance. This could be a "meeting point" between the Tolaki'smoseherite and the atonement of Christ.

Gustav Aulen, as quoted by E.G. Singgih, said that there are at least three types or models of understanding of the atonement of Christ, namely the latin type, exemplary type and classical type[31]. Aulen said in the Latin type the emphasis is on the actions of humans who pay compensation, even though that person is the Son of God in Jesus' person. In this Latin type, what happens is the human movement toward God, while in the classical type the pressure is in the movement of God toward humans. In this classic type Aulen unites incarnation with atonement. Humans who fall into sin are under threat from cosmic powers, and God's action through Christ is to free men from the grip of that power. On the cross Christ appears as a helpless creature, but in fact that is where the almighty God is hidden [32].

\section{d) The Cosmological Dimension of the Atonement: Christ Reconciled and Redeemed All Creation}

In the reconciliation ceremony performed by the Tolaki people, it was shown that reconciliation was not only about improving relations between Sangiaand humans and humans with creation. Atonement also involves improving relations with the universe. The victim (sehe) in the rite freed the universe, animals and plants from the disaster as a result of traditional violations. Customary violations committed by someone according to Tolaki's understanding do not only bring disaster to the perpetrators of violations. Disasters will also afflict the universe or cause disharmony in the cosmos.

From the explanation above shows that Tolaki people sees his existence with the universe as a subject-matter relationship. This means that humans and the universe have the same position, as a creature[33]. Because the nature has a meaning as well as human life, so that nature must be valued and treated well. 
God reconciles Himself with everything (Col. 1: 20). This means that in the work of Christ's atonement, the universe is placed in its original position, that is, a harmonious relationship with humans[34]. God has come to fulfil His promise in Jesus Christ. God expresses His love in creation, covenants and fulfillments of promises, when He comes to redeem all creation. The coming of Christ brings new perspective in relationship between man and nature.

The culmination of God's redemption and renewal of His creation is through Christ. Renewal of creation has been fulfilled in Christ. God's love which is the basis of creation is also the basis of God's atonement (salvation). In Colossians 1: 16-17, Christ is portrayed as the intermediary and basis of creation, so Christ is also the intermediary and basis of God's atonement (salvation) and redemption. In Christ, God has reconciled Himself with everything (Colossians 1: 20; 2 Corinthians 5: 18-19). Various expressions in the New Testament, especially those relating to the historical event of Christ, as pointed out in Colossians, emphasise that the work of atonement and redemption of creation has been fulfilled in Christ.

GEPSULTRA's understanding the Atonement of Christ in the text of Colossians 1: 15-23, only emphasise humans as objects of Christ's atonement.As mentioned above, in providing guidance or theological understanding to members of the church regarding the concept of salvation, it does not touch the cosmological aspects. Not surprisingly, the area around the congregation suffered severe environmental damage due to exploitation by a mining company. Ironically, the church, both at the level of the congregation and at the synodal level, is quiet about the problem.

Such an anthropocentric view would opposite with the understanding of the Tolaki people who saw that all creation and the universe were part of the reconciliation of the Creator. The moseherite, besides having implications on human life, also has a cosmic aspect. The reconciliation dimension of the atonement rite (mosehe) includes the reconciliation of human relations with the world of the gods (and the ancestors), the reconciliation of human relations with each other, and atonement which has a cosmological dimension. GEPSULTRA can use the concept of the atonement dimension of Christ in Colossians 1: 15-23 as a theologicalbiblical reference. In addition, as Tolaki still see the values of local wisdom in the moseherite which has been renewed by Christ (in accordance with the Gospel) to develop contextualization in Southeast Sulawesi. Christ's reconciliation goal which has a cosmic dimension does not contradict this preaching of Colossians 1: 20. YusakTridarmanto, quoting Fitzmyer's opinion, wrote that in the light of Colossians 1:20 it seems clear that the atonement was not only about human relations with God, but also the universe[35]. Thegoal of reconciliation which is not limited to humans, includes the cosmic aspect, due to God's main will is to renew the broken relationship between himself and this world.

The Tolaki people see themselves with the universe or other creatures in subject relations. The point is that humans and the universe/other creatures have the same position as creatures and have one and the same creator, SangiaMbu'u(the divine). The principle of equality of creation in the Tolaki's view can be used as a starting point in building a contextual ecotheology, especially for GEPSULTRA. The appreciation of the work of reconciliation (read: salvation) of God through Christ developed by GEPSULTRA cannot rule out the universe as the object of the atonement's work.

Therefore, humans should develop the principles of ethical solidarity within the framework of their position as a creation with another creation. These ethical principles of solidarity can be used as a reference in applying contextual ecology in daily life. The author refers to the ethical principles of solidarity that can be seen from the local wisdom values of the moseherite. The principles: 
1. The attitude of respect for nature. Respect for nature is a basic principle for humans as part of nature as a whole and an integral part of nature. Nature has the right to be respected, not only because human life depends on nature, but because ontologically humans are an integral part of nature. From the theoretical perspective of natural rights, humans as moral agents (moral agents) are obliged to respect the natural life, the lives of all the creations in it. Human being must be care for, maintain, protect and preserve nature along with all its contents.

2. The principle of responsibility. Associated with the principle of respect, humans must be responsible for nature, both as individuals and collectively. Each individual and collective is required and called to preserve the universe. This responsibility requires humans to take initiatives, efforts, policies and concrete actions to preserve the universe with all its contents. This responsibility is not just for the benefit of humans, but because nature has a value in itself.

3. Cosmic solidarity. This principle arises from the fact that humans are an integral part of the universe. More than that, humans have an equal position with the universe and other creations, so that feelings of solidarity or compulsion become part of the life of every creation including humans in the universe. This fact arouses in humans a feeling of solidarity or continuity with the universe and fellow creatures. This principle encourages humans to save the environment and all this natural life. Cosmic solidarity prevents people from acting in the way of destroying and polluting nature and all life in it, just as humans do not damage the household rumors themselves. Cosmic solidarity functions as a moral controller (a kind of taboo in traditional society), so that harmony is always created in the universe. This principle makes humans will take a pro-natural attitude and pro-environment.

4. The principle of compassion and care for nature. This principle is strongly emphasized by ecofeminists. This principle emphasizes the equality of the ecological community that inspires humans to love, love nature without discrimination. This principle is not based on personal interests or human interests, but also in the interest of the universe.

5. The principle does not damage. Humans must not take actions that can harm or threaten the existence of other living things in the universe. Meeting the needs of human life is only done in accordance with the most vital needs of moral obligations and responsibilities that can be done in this case is to take action to care for, protect, preserve and preserve nature. Conversely, actions that harm the universe,such as disposing of waste that damage ecosystems, destroying certain species and so on are against this principle.

6. The principle of justice. This principle mainly talks about the equal access of all community members to participate in determining natural resource management policies and their preservation. This principle includes that all groups and members of society must proportionately bear the burden caused by damage to the universe. Groups that receive greater benefits from nature, for example groups that receive logging concessions, must have a greater responsibility for efforts to restore, preserve and care for nature.

7. The principle of life is simple and in harmony with the universe. This principle emphasizes values, quality, a good way of life, not engineering, not greed and so on. The most important thing is a good quality of life. Nature must not be made an object to be exploited for the satisfaction of the human heart. This means that the patterns of consumption and production of modern humans must be limited. There must be limits that can be tolerated by nature. Indeed we do not have criteria in that regard, because 
this problem is related to certain lifestyles and cultures. As long as materialistic, consumptive and exploitative lifestyles are applied by humans, it will certainly be difficult to save the universe.

8. The principle of democracy. This principle is related to the nature of nature that is always diverse. The principle of democracy is very relevant in making policies in the environmental field. This principle gives freedom for every person or community group to fight for the interests of the environment, participate in determining policies in the environmental field and have the right to obtain transparent information in the environmental field.

9. Principle of moral integration. This principle is primarily intended for public officials to have respectable behavior and morals so that it can be an example for the public. If public officials do not have moral integrity to nature or the environment and other creations, then it can be guessed how the fate of nature and other creations in relation to the policies taken.

From the ethical principles above, it can be concluded that humans are part of the ecological community as a whole and intact.Thus, the moral community is not restricted to humans, but applies to all ecological communities. Indeed, only humans are moral agents, but all nature must be seen as moral subjects.

\section{Conclusion}

From the perspective of the Tolakimosehe rite, Christ's atonement in Colossians 1: 15-23 is universal atonement; the atonement which encompasses all creation. Humans and non-human creations fall within the scope of Christ's atonement. Sin has implications for the destruction of the records of all creation. Abalaas a result of sin not only has a personal dimension, but also has an influence on the communal and even cosmic dimensions. Therefore there needs to be an act of reconciliation to restore relations that have been affected by abala. In the mosehe rite, the atonement victim (sehe) has the role of rejecting the abala while at the same time restoring - renewing the whole order of creation, both human and non-human. From the local wisdom of the moseherite, GEPSULTRA can develop contextual eco-theology, especially cosmic soteriology.The church will be more sensitive to the preservation of nature and the environment. There are even ethical and ecclesiological responsibilities in caring for biodiversity as part of the church's mission in it.

\section{References}

[1] A. Sonny Keraf. (2010), Krisis dan Bencana Lingkungan Hidup Global. Yogyakarta: Kanisius, 27-59.

[2] Sunarko dan A. Eddy Kristiyanto. (2008), Menyapa Bumi Menyembah yang Ilahi. Yogyakarta: Kanisius, 56.

[3] Suparman Sultan (2019), "Jadi Lokasi Penambangan, Hutan Di Kolaka Rusak Hingga 5 Hektar. https://regional.kompas.com/read/2017/04/28/14022151/jadi.lokasi.penambangan.emas.hutan.di. kolaka.rusak.hingga.5.hektar (accessed August 14, 2019). 
[4] Rosniawanty Fikri, (2019). "PT. Aneka Tambang Tbk Bantah Cemari Perairan Sultra,https://nasional.tempo.co/read/858640/antam-bantah-cemari-perairan-sultra (accessed August 14, 2019).

[5] Stephen Bevans (2002), Models of Contextual Theology. Maryknoll, NY: Orbis Books, 34.

[6] Salmon Pamantung. (2019), "Hermeneutik Kontekstual: Peran Sudut Pandang Penafsir dalam Memahami Teks" dalam Mozaik Moderasi Beragama dalam Perspektif Kristen. (Jakarta: BPK Gunung Mulia, 2019), 234-247). See also Daniel K. Listijabudi, Bergulat di Tepian: Pembacaan Lintas TekstualDuaKisahMistik (Dewa Ruci dan Yakub di Yabok) untuk Membangun Perdamaian. (Jakarta: BPK Gunung Mulia, 2019), p. 33.

[7] Lynn White Jr., "The Historical Roots of Our Ecological Crisis” in David \&Eileen Spring (Eds), Ecology and Religion in History, (New York: Harper and Row, 1974). pp.35-37.

[8] Lynn White Jr., "The Historical Roots of Our Ecological Crisis" in David \&Eileen Spring (Eds), Ecology and Religion in History, (New York: Harper and Row, 1974). pp.35-37.

[9] John Salmon, "Christology and Climate Change", Systematic Theology Association of AotearoaNew Zealand in the City Presbyterian Church, Wellington 30 November-1 December, 2006, accessed at http://www.saintcolumbas.org.nz/climatechange.pdf

[10] Hannah Arendt, Human Condition(Second Edition), (Chicago \& London: The University of Chicago Press, 1998). p. 76.

[11] Thomas Berry "The Spirituality of Earth" in Charles Birh, William Eakin and Jay B. MacDaniel (ed.), Liberating of Life: Contemporary Approaches to Ecological Theology. New York: Orbis Book, 1990, p. 151.

[12] Jurgen Moltmann, "Reconciliation with Nature", in Word and World (11/2), 1991, pp. 117-123.

[13] KwokPuiLan, Ecology and Christology. (London: Continuum International Publishing Group Ltd, 2004), p. 15.

[14] Sallie Mc Fague, The Body of God:An Ecological Theology. (UK: Fortress Press, 1993), p. 45.

[15] Sallie Mc Fague, The Body of God:An Ecological Theology. (UK: Fortress Press, 1993), p. 45.

[16] Karel Phil Erari, Tanah Kita, Hidup Kita: Hubungan Manusia dan Tanah di Irian Jaya sebagai Panggilan Teologis, (Jakarta: Sinar Harapan, 1999).

[17] Central Statistics of Sulawesi Provincial Government reported, the population of Muslims is 64\%, Christians 21\%, Catholics 9\%, Hindus and Buddhists 10\%. See Badan Pusat StatistikProvinsi Sulawesi Tenggara, "Jumlah Penduduk Menurut Kabupaten/Kota dan Agama yang Dianut di Provinsi https://sultra.bps.go.id/dynamictable/2018/08/31/110/jumlah-penduduk-menurut-kabupatenkota-dan-agama-yang-dianut-di-provinsi-sulawesi-tenggara-2016.html (accessed August 18, 2019).

[18] Abdurrauf Tarimana, Kebudayaan Tolaki (Jakarta: Balai Pustaka 1989), p. 227.

[19] Abdurrauf Tarimana, Kebudayaan Tolaki (Jakarta: Balai Pustaka 1989), p. 227.

[20] Bine, interviewed, Konawe, August 7, 2019. (Bine is a shaman (mbusehe) in Wolio village).

[21] Eduard Lohse, Colossians and Philemon: A Commentary on the Epistle to the Colossians and Philemon (Philadelphia: Fortress Press, 1971), p. 46.

[22] Peter O'Brien, Colossians, Philemon: Word Biblical Commentary Vol. 44 (Texas: Word Books Publisher, 1982), p. 61.

[23] Theological Dictionary of the New Testament, volume I, s.v."katallasw"dan James D. G. Dunn, The Epistles to the Colossians and to Philemon: A Commentary on the Greek Text (Grand Rapids: W. B. Eerdmans Publishing Company, 1996), pp. 102-103.

[24] Yusak Tridarmanto, "Perdamaian dan Rekonsiliasi: Telaah dari Sisi Perjanjian Baru" dalam Perempuan, Konflik dan Rekonsiliasi: Perspektif Teologi dan Praksis, peny. Basilica Dyah Putranti dan Asnath Niwa Natar (Yogyakarta: Pusat Studi Feminis Universitas Kristen Duta Wacana, 2004), p. 21.

[25] See Romans 5: 10; II Corinthians 5: 19.

[26] Lohse, Colossians and Philemon, p. 63.

[27] R. Bultmann, Theology of New Testament I (London: SCM Press, 1952), p. 292.

[28] Dunn, The Epistles to the Colossians, p. 113. 
[29] Kamus Besar Bahasa Indonesia, s.v. "kurban."

[30] Disasters are often regarded as the work of evil powers. Pandiu, interviewed, Konawe, June, 27 2019.

[31] See E. G. Singgih, Iman dan Politik dalam Era Reformasi di Indonesia (Jakarta: BPK Gunung Mulia, 2000), p. 164.

[32] See E. G. Singgih, Iman dan Politik dalam Era Reformasi di Indonesia (Jakarta: BPK Gunung Mulia, 2000), p. 164.

[33] See A. G. Honig, Ilmu Agama (Djakarta: BPK Gunung Mulia, 1966), p. 16.

[34] A. A. Yewangoe, Pendamaian (Jakarta: BPK Gunung Mulia, 1983), p. 182.

[35] Tridarmanto, "Perdamaian dan Rekonsiliasi: Telaah dari Sisi Perjanjian Baru", p. 43. 